\title{
流動限界と損失エネルギーによる まさ土の液状化特性の評価
}

\author{
中山義久 ${ }^{1} \cdot$ 西田一彦 ${ }^{2} \cdot$ 西形達明 $^{3} \cdot$ 井上啓司 ${ }^{4}$ \\ ${ }^{1}$ 正会員 工修 協同組合 関西土質研究センター 課長（テ566-0042 大阪府攝津市東別府 1 丁目 3-3 ) \\ 2 正会員 工博 関西大学 教授 工学部土木工学科（广564-0073 大阪府吹田市山手町 3 丁目 3-1） \\ 3 正会員 工博 関西大学 助教授 工学部土木工学科（甬564-0073 大阪府吹田市山手町 3 丁目 3-1) \\ ${ }^{4}$ 正会員 協同組合 関西土質研究センター 専務理事 （广566-0042 大阪府摄津市東別府 1 丁目 3-3）
}

まさ土の液状化強度曲線および夜状化に至る変形挙動と供試体内で消費される損失エネルギーの関係をまさ土の物性值で ある流動限界をもとに調へた．実験には締固めた供試体と絽返し三軸詿験機を用いた．その結果，圧密後の間隙比と流動限 界で液状化時までの累積損失エネルギー量が決まること，および累積損失エネルギ一量から液状化強度曲線を推定できるこ とが分かった. さらに, 液状化に至るまでの変形特性についても考察し, 変形倸数比の低下は累積損失エネルギ一量と双曲 線関係にあること, およひ双曲線の定数と流動限界との関係について示した.

Key Words: decomposed granite soil, liquefaction, void ratio, grain size, consistency, dissipation energy

\section{1. はじめに}

比較的粒度のよい花風岩の風化残積土であるまさ土は 液状化強度が高く, 良質な埋め立て材として知られ, とく に関西周辺では臨海部の埋め立て地盤材として多用され てきた. しかし, 1995 年の兵庫県南部地震において, ま さ土地艋が液状化したことは周知の通りである. そして, これを機にまさ土の液状化に関する研究が再度活発に行 われるようになった. 筆者らはまさ土を対象とした場合, その液状化特性を細粒分含有率や平均粒径だけで評価す ることは不十分であることを指摘し, 砂質土のコンシステ ンシーと等価な流動限界を指標とすれば, まさ土の液状化 強度の評価が可能であることを示した ${ }^{1)}$. また，このよう な砂質土の液状化に至るまでの変形特性も重要なポイン トであり,これについては従来より損失エネルギーをもと に検討が加えられている.

損失エネルギーと液状化に至る变形挙動の関係を調べ たものとして Towhata and Ishihara ${ }^{2}$ は中空ねじりせん断 試験機を, 坂井・落合 ${ }^{3}$ は振動三軸試験機を, また片田・ 阿部・東山 ${ }^{4)}$ はオンライン地震応答載荷装置を用い，豊 浦砂に対してそれぞれ液状化試験を実施している. それら の研究によると, 累積損失エネルギーを用いると, たとえ 応力経路の異なる液状化試験を実施しても, それぞれから 得られる過剩間隙水圧を統一的に整理することが可能で あることが示されている.しかし，これらの研究において は液状化に至る過程の変形特性と累積損失エネルギーの 関係についてはあまり言及されていないように思われる.

一方, 風閒ら は砂質土, まさ土に対して定ひずみ制御
繰返し三軸試験による液状化試験を行い, 累積損失エネル ギーと過㮃間隙水圧, およびせん断岡性の低下の関係が一 義的に求められることを明らかにしている.さらに風間ら は累積損失エネルギーを用いて，地震時にまさ土地盤に 発生する過㮃間隙水圧やせん断岡性低下の予測をしてい る.この予測の特徵は地盤の液状化の有無ではなく, 勒 性・ねばりの影響を考慮していることにある.

このように累積損失エネルギーと液状化に至る過程に おける変形抵抗との関係を明確にすることが重要である. そこで本研究では, 関西に数多く分布するまさ土の液状化 過程におけるせん断剛性低下の挙動と, 繰返し載荷中の累 積損失エネルギーとの関係を明らかにし，個々のまさ土に 対して物理・力学的性質と密接な関係にある流動限界を物 性値の指標として考察したものである.

\section{2. 用いた試料の特徴と実験方法}

実験で用いた試料は表ー 1 に示すように生駒山系, 5 種 類 (B 試料, $\mathrm{W} \cdot \mathrm{S}$ 試料, $\mathrm{Y} \cdot \mathrm{K}$ 試料) と六甲山系, 4 種類 (RA, $\mathrm{RB}$ 試料, $\mathrm{TK}$ 試料, $\mathrm{T}$ 試料) およひ淡路島 1 種類 ( $\mathrm{AW}$ 試料) である. まさ土は母岩, 産地, 風化の程度により軟岩から 細粒土に近いものまで存在するが本研究で使用した試料 は関西地区で採取されるまさ土のほぼ代表的なものとな っている. なお, 各試料の粒度は文献 1)を参照されたい.

$2 \mathrm{~mm}$ ふるい通過試料を用い, 直径 $50 \mathrm{~mm}$, 高さ $100 \mathrm{~mm}$ の円 柱供試体となるように 3 層に分け, 締固めて作製した. 試 験試料の乾燥密度は最小・最大密度試験より得られた結果 
表一 1 試料の物性值

\begin{tabular}{|c|c|c|c|c|c|}
\hline $\begin{array}{l}\text { צ } \\
1 \\
7\end{array}$ & 産地 & 試料名 & $\begin{array}{c}\text { 平圴粒径 } \\
D_{50}(\mathrm{~mm})\end{array}$ & $\begin{array}{l}\text { 細粒分 } \\
\text { 含有率 } \\
F_{C}(\%) \\
\end{array}$ & $\begin{array}{c}\text { 流動 } \\
\text { 限界 } \\
\mathrm{w}_{f}(\%) \\
\end{array}$ \\
\hline \multirow{14}{*}{$\begin{array}{l}\text { 領 } \\
\text { 型 }\end{array}$} & \multirow{13}{*}{$\begin{array}{l}\text { 生駒 } \\
\text { 山地 }\end{array}$} & B1 & 0.066 & 55.0 & 40.5 \\
\hline & & B2 & 0.057 & 58.0 & 41.5 \\
\hline & & B3 & 0.170 & 31.0 & 28.0 \\
\hline & & W1 & 0.330 & 23.0 & 23.0 \\
\hline & & W2 & 0.380 & 12.0 & 21.0 \\
\hline & & W3 & 0.460 & 16.0 & 18.2 \\
\hline & & $\mathrm{Y} 1$ & 1.200 & 16.0 & 28.5 \\
\hline & & Y2 & 0.210 & 15.0 & 24.0 \\
\hline & & Y3 & 0.71 & 12.0 & 22.6 \\
\hline & & $\mathrm{KH}$ & 2.500 & 13.6 & 29.1 \\
\hline & & $\mathbf{K L}$ & 2.500 & 16.7 & 25.1 \\
\hline & & SH & 0.670 & 13.9 & 26.7 \\
\hline & & SL & 0.790 & 24.7 & 25.6 \\
\hline & 淡路島 & AW & 2.000 & 14.0 & 35.8 \\
\hline \multirow{6}{*}{$\begin{array}{l}\text { 公 } \\
\text { 型 }\end{array}$} & \multirow{6}{*}{$\begin{array}{c}\text { 六甲 } \\
\text { 山 }\end{array}$} & RA & 2.600 & 16.9 & 18.0 \\
\hline & & RB & 0.550 & 16.0 & 19.1 \\
\hline & & TK & 3.020 & 15.0 & 18.0 \\
\hline & & TA & 2.280 & 13.2 & 22.2 \\
\hline & & TB & 2.200 & 16.6 & 33.4 \\
\hline & & TC & 2.000 & 15.5 & 33.5 \\
\hline
\end{tabular}

をもとに緩詰めから密詰めまで $3 \sim 5$ 種類の值を設定した. 締固め後, 自立しない供試体については凍結した後, 三軸 セル内で 2 時間以上かけて解凍した. そして， $\mathrm{CO}_{2}$ 通気と 脱気水通水後, $196 \mathrm{kPa}$ の背圧を負荷し, B 值が 0.95 以上 であることを確認して， $\sigma_{0}^{\prime}=98 \mathrm{kPa}$ て等方圧密を行った 後, 液状化試験を行った. 繰返し載荷は荷重制御による周 波数 $0.1 \mathrm{~Hz}$ のサイン波とし, 側圧一定の非排水条件で行っ た. 本研究では液状化を生じ易い比較的浅い飽和地盤の有 効土被り圧を想定して圧密圧力を $98 \mathrm{kPa}$ に統一した. 繰返 し応力振幅比 $\mathrm{r}=\sigma_{\mathrm{d}} / 2 \sigma_{0}$ 'である. ただし， $\sigma_{\mathrm{d}}$ は繰返し軸 差応力である.

\section{3. まさ土の液状化強度特性}

\section{（1）過剩間隙水圧の発生挙動}

図-1 は液状化試験より得られる液状化強度曲線を示し ている. 液状化強度比は各供試体ごとに軸ひずみ両振幅 $\mathrm{DA}=5 \%$ となる繰返し載荷回数と, 繰返し応力振幅比の関係 から載荷回数 20 回時で求めたものである．流動限界によ る影響をみるために, 圧密後の間隙比がほぼ等しく流動限 界の異なる試料の液状化強度曲線を示している.この図を みると, 流動限界が大きくなると液状化強度比が大きくな っており，まさ土の液状化強度比は流動限界に大きく影響
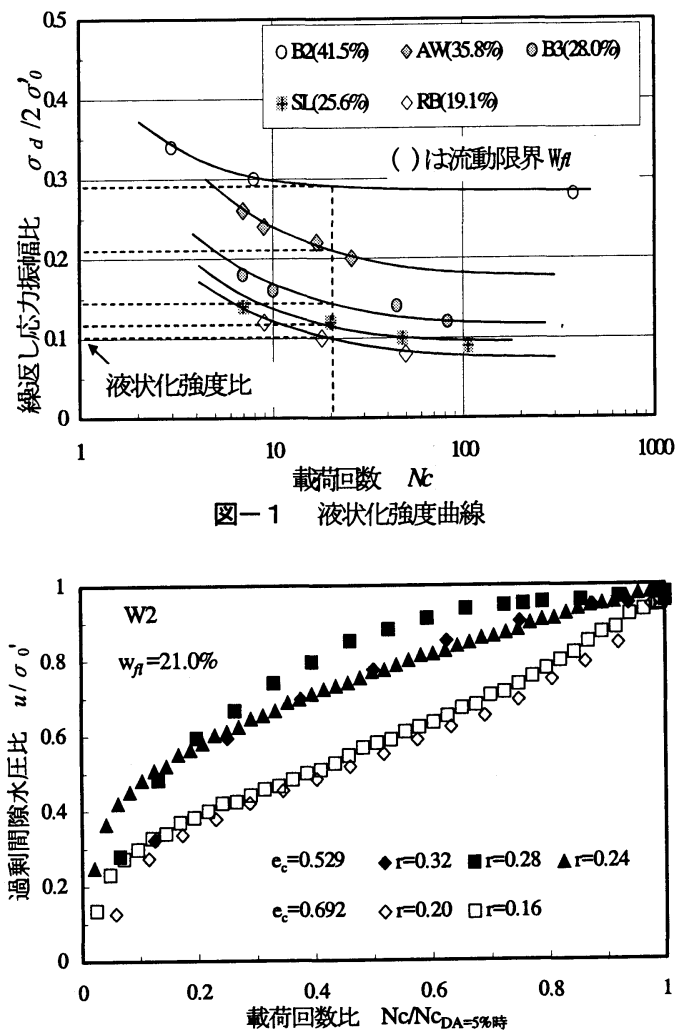

図-2 間隙水圧と載荷回数比の関係(W2 試料)

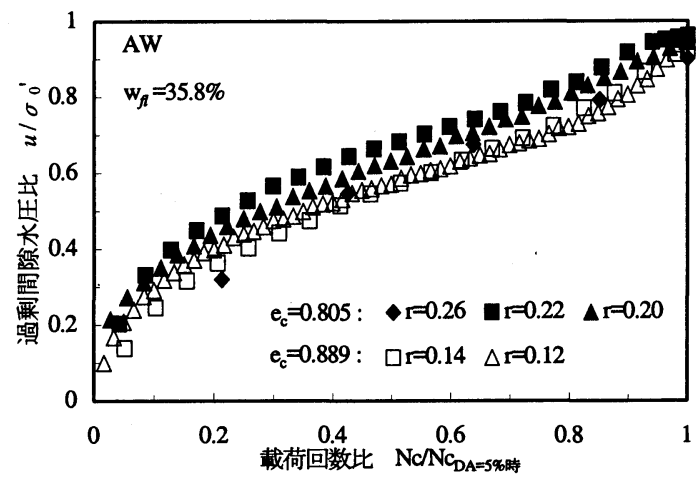

図-3 間隙水圧と載荷回数比の関係(AW 試料)

を受けることがわかる. したがって流動限界はまさ土の液 状化強度特性と密接な関係を有しているものと考えられ る. そこで, 液状化過程におけるまさ土の液状化に至るま での変形挙動について考える上で損失エネルギーに注目 し,これと流動限界との関係を明らかにすることで液状化 時の変形特性を流動限界によって整理することを試みる.

まず，液状化 $(\mathrm{DA}=5 \%)$ に至るまでの間隙水圧の発生経路 を示したものが図一2, 図-3である. 図-2 は流動限界の小 さいW2 試料の試験結果を, 図-3 は流動限界の大きいAW 


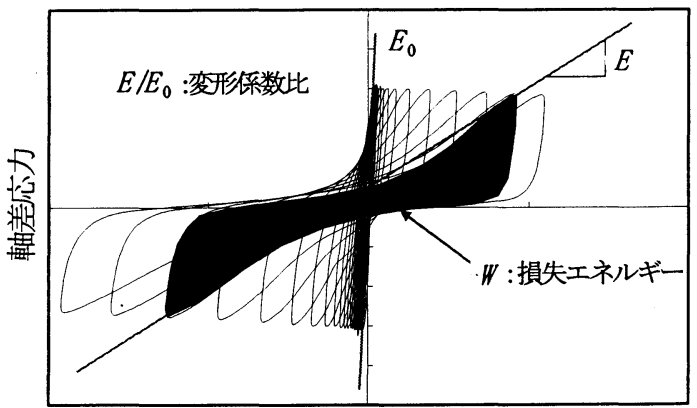

軸ひずみ

図一4 ヒステリシスループの模式図

試料の試験結果を示している. 図は䋛軸に過剩間隙水圧比， 横軸には軸ひずみ両振幅 $\mathrm{DA}=5 \%$ 時の回数で除した載荷回 数比をとった. 過剩間隙水圧は繰返し載荷中に変動するが 図中の点は安全側を想定して 1 サイクルごとの最大值を とった. なお，両図ともに黒塗りは密詰め試料を表し，白 抜きは緩詰め試料の場合を表している．まず，図-2 をみ ると, 間隙比の違いによる過剩間隙水圧の発生経路には顕 著な違いがみられるが, 同一間隙比においては応力比が異 なってもほぼ同一の過剩間隙水圧発生経路を示している. 一方，流動限界の大きい図-3 をみると，間隙比の違いに 関わらず間隙水圧の発生経路はほぼ同一になっているこ とがわかる.

次に, 図-4 は繰返し載荷によって描かれるヒステリシ スループの模式図である.1つの履歷曲線で囲まれた面積 が繰返し回数 1 回あたりに供試体内部で変形に費やされ たエネルギーを示している.このエネルギーを損失エネル ギーW $\left(\mathrm{kN} \cdot \mathrm{m} / \mathrm{m}^{3}\right)$ と定義し，載荷によって累積されたものを 累積損失エネルギー $\Sigma W\left(\mathrm{kN} \cdot \mathrm{m} / \mathrm{m}^{3}\right)$ とした. また, このヒス テリシスループの頂点を結ぶ直線の勾配を変形俰数 $E$ と し, 繰返し載荷第 1 波目の勾配を $E_{0}$ として, 任意の載荷 回数に対する変形係数比 $E / E_{0}$ を変形特性の変化の指標と して用いることにした.

図-5 はW2 試料，図-6 はAW 試料の試験結果を示してい る. 緹軸には過剩間隙水圧比，横軸に累積損失エネルギー を軸ひずみ振幅 $\mathrm{DA}=5 \%$ 時の累積損失エネルギーで正規化 したものをとった. 以下，これを累積損失エネルギー比と 呼ぶ. 両図をみると, 流動限界の小さい試料では, 間隙比 の違いによって多少の差がみられるが, 全体的な間隙水圧 の発生経路には大きな差はみられない. とくに, 流動限界 の大きいまさ土になると,いずれの条件でも過剩間隙水圧 の発生経路はほほ等しくなっている.

以上の結果より, 載荷回数比でまとめたものでは閒隙比 の違いによって間隙水圧の発生経路に差が生じたが, 累積 損失エネルギー比で表現すると，同様な発生経路になる. この結果より, 液状化過程における過剩間隙水圧の発生挙
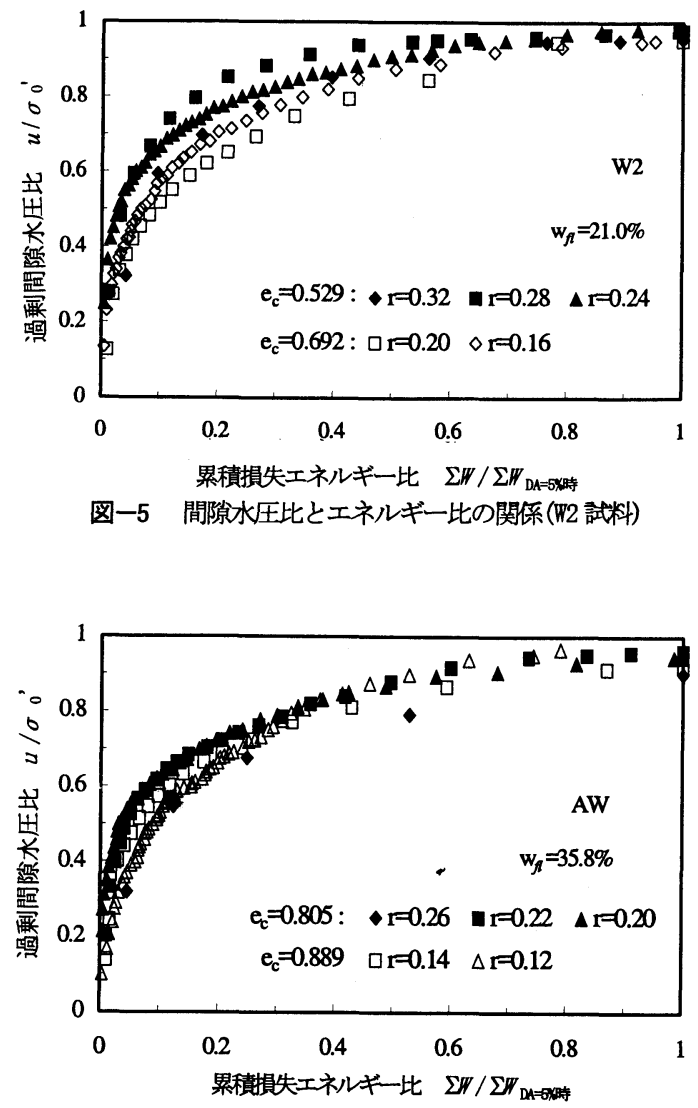

図一6 間隙水圧比とエネルギー比の関係(AW 試料)

動は累積損失エネルギーによって統一的に表現しうるこ とがわかる。

\section{（2）液状化時の累積損失エネルギ}

流動限界の小さい試料( $\left.\mathbb{W}_{f}<30 \%\right)$ と流動限界の大きい試

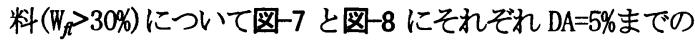
累積損失エネルギーと載荷回数の関係を示した.これらの 図をみると, 同一間隙比の試料について繰返し応力振幅応 力比 $\mathrm{r}$ が 0.3 より小さい範囲では, $\mathrm{r}$ の違いに関わらず夜 状化時の累積損失エネルギー $\Sigma W\left(\mathrm{kN} \cdot \mathrm{m} / \mathrm{m}^{3}\right)$ は等しくなっ ていることがわかる.このことは液状化強度曲線は等累積 損失エネルギ一線と等価であることを示している.さらに, この累積損失エネルギーの值は間隙比が小さくなるほど 大きくなっている. また, 流動限界の違いに注目すると, 流動限界の大きい試料の方が液状化時の累積損失エネル ギーの值は大きくなっていることがわかる.

以上の結果より, 液状化に至るまでの累積損失エネルギ 一は繰返し応力振幅比が 0.3 より小さい範囲では間隙比 と流動限界によって表すことができるものと考えられる. そこで, 全試料を液状化に至るまでの累積損失エネルギー 


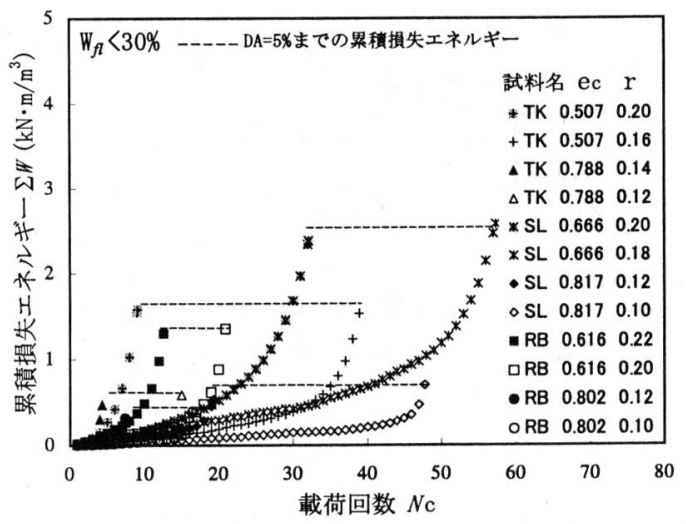

図一7 累積損失エネルギーと載荷回数の関係(流動限界 $<30 \%)$

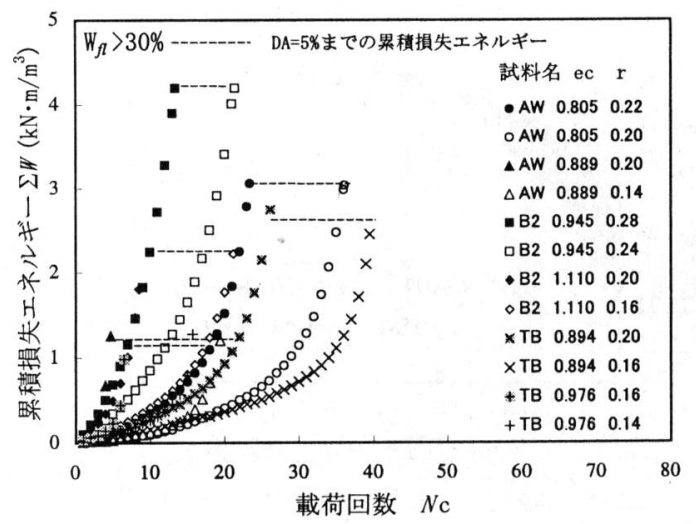

図一8 累積損失エネルギーと載荷回数の関係 (流動限界>30\%)
と流動限界の図上にプロットすると図-9のようになる. なお, 図中の值は圧密後の間隙比を表している.この図で, ほぼ同じ間隙比の值を等閒隙比線として結ぶと液状化に 至るまでの累積損失エネルギーと流動限界は図中のよう な曲線関係を持つことになる.これより, まさ土の閒隙比 と流動限界がわかれば, 液化時の累積損失エネルギ一の推 定が可能となる.

\section{4. 液状化強度曲線の推定}

以上に得られた結果を用いると液状化時の累積損失エ ネルギーを用いて液状化強度曲線の推定を行うことが可 能となる. 図-10 は本研究で害施したすべての実験におけ

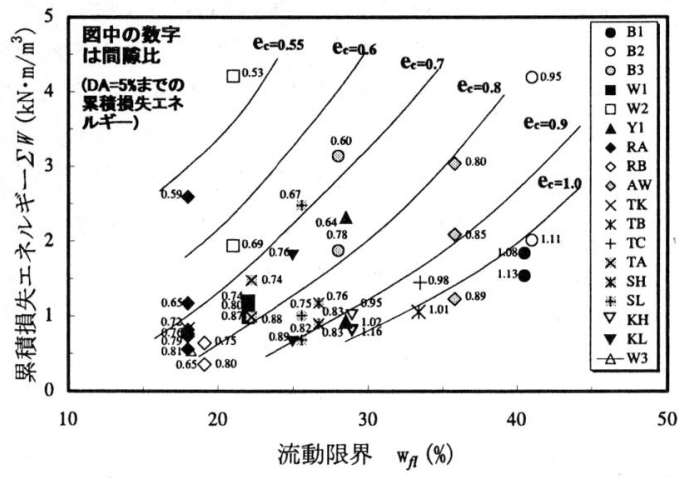

図一9＼cjkstart累積損失エネルギーと流動限界の関係

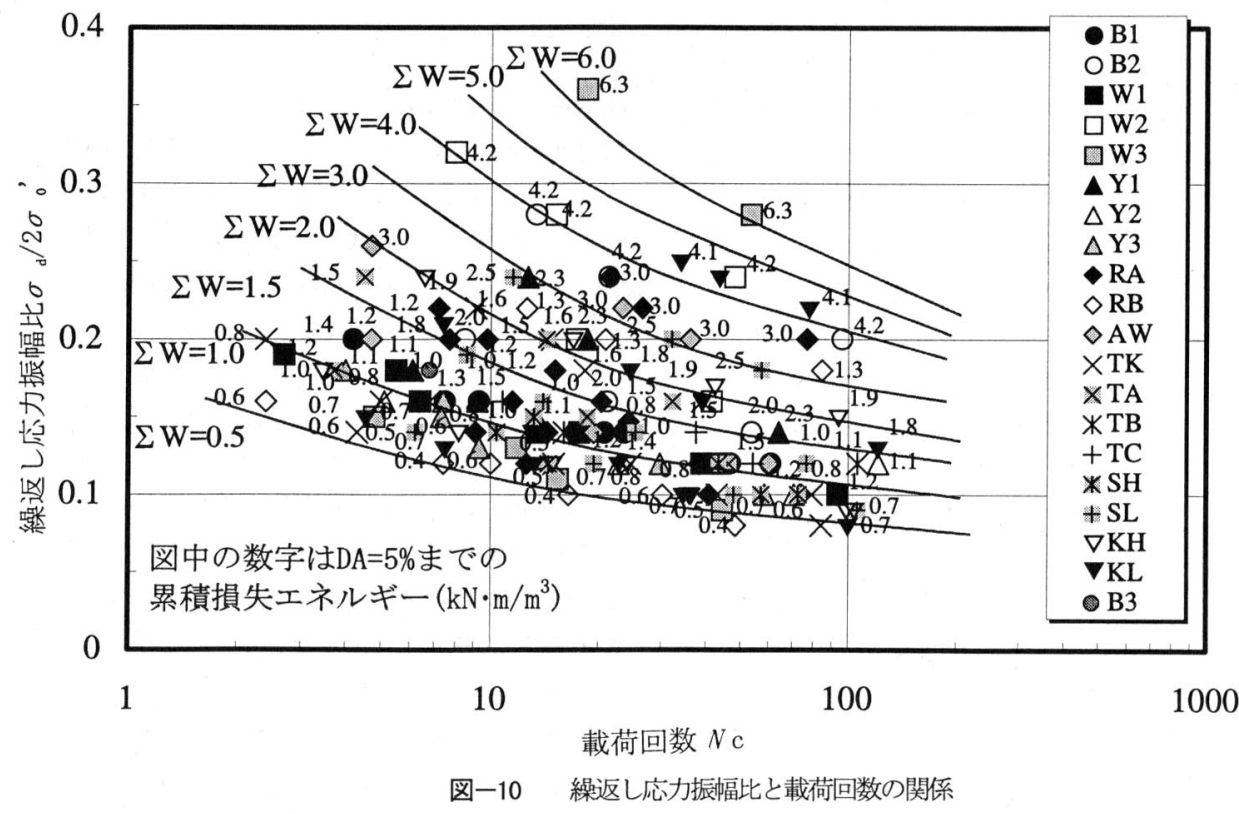




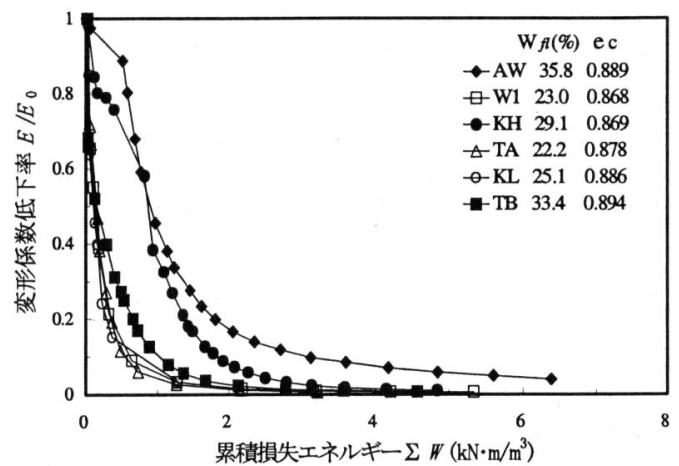

図-11 变形係数比の低下率と累積損失エネルギーの関倸

る液状化時の綝返し応力比 $\sigma_{\mathrm{d}} / 2 \sigma_{0}$ ' 載荷回数 $N \mathrm{c}$ の関倸 を示している. なお，図中の值はそれぞれの $\mathrm{DA}=5 \%$ までの 累積損失エネルギーを示している.多少のばらつきはみら れるが, 図中に示すような等累積損失エネルギー線を引く ことができる.液状化強度曲線は等エネルギ一線と等価で あるとすると個々の線は液状化強度曲線そのものである ことがわかる. したがって, この図より, 液状化時の累積 損失エネルギーがわかれば, 容易に液状化強度曲線を推定 することができる. これにより，まさ土の物性值としての 流動限界と状態量としての圧密後の間隙比を知ることに より図一9 から液状化時の累積損失エネルギ一值を求め, この值から図一10 を用いることで夜状化強度曲線を簡便 的に推定することができる.

\section{5. 液状化過程における変形特性}

現在, 液状化の予測をするためには液状化強度を知るこ とが主眼となっている7),8). しかし, 液状化強度のように 液状化する, しないの 2 極的な考え方では液状化強度の定 義の仕方により過大評価や過小評価する可能性がある. 破 壊に至らなくとも大きな変形を生じると構造物は機能し なくなることなどを考えると,これからの耐震設計を考え る上でその変形特性を検討することが非常に重要である. そこで,ここでは前節で説明した変形倸数比の低下率に注 目し, 土が繰返しせん断を受けて液状化に至るまでの変形 係数の低下について検討する. そして, 前述までの液状化 強度の推定法と同様に流動限界と変形係数の低下挙動の 関係を明らかにすることを試みる.

繰返し載荷に伴う変形倸数比の低下挙動の表現には載 荷回数, 間隙水圧, 累積損失エネルギーなどを用いる方法 があるが,ここでは前章までに述べてきた累積損失エネル ギーと変形係数比の関倸に注目する．図一11 は緃軸に変 形係数比 $E / E_{0}$ を, 横軸に $\mathrm{DA}=5 \%$ に至るまでの累積損失エネ ルギー $\Sigma W\left(\mathrm{kN} \cdot \mathrm{m} / \mathrm{m}^{3}\right)$ をとったものである.この図では流動
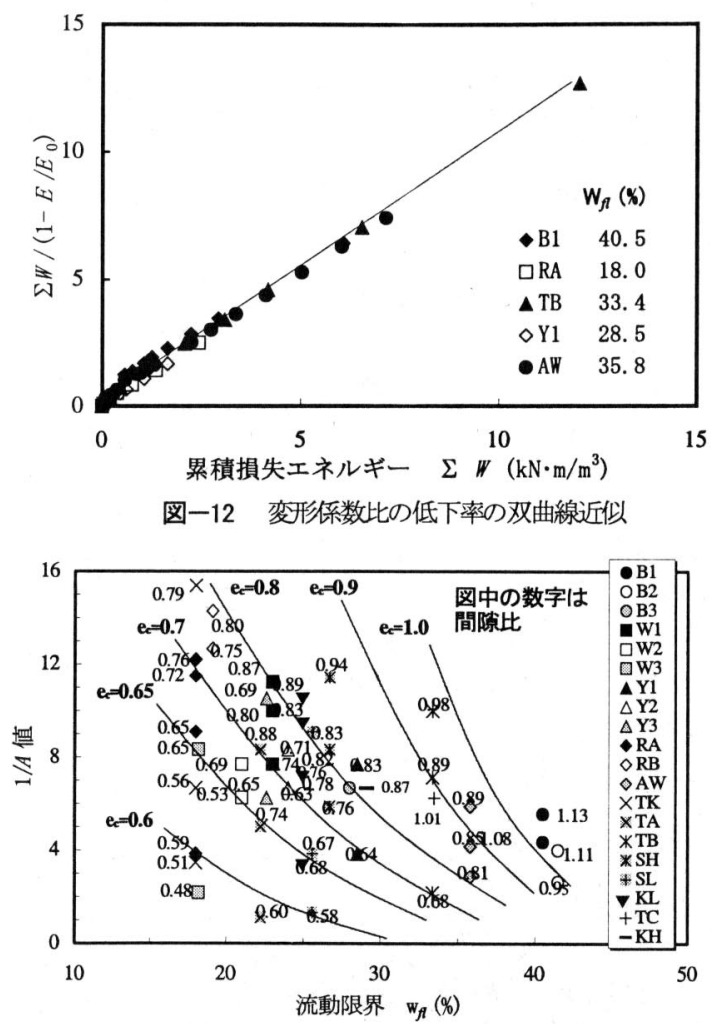

図-13 定数 $1 / A$ と流動限界の関倸

限界による影響をみるために, 間隙比, 応力比がほぼ等し く，流動限界の異なる場合の結果を示した. この図より, 流動限界が 20〜25\%の範囲では変形係数比の低下挙動に 大きな違いはみられないが, 流動限界が大きくなると変形 俰数比の低下曲線の勾配が緩やかになっており, 損失エネ ルギーの蓄積量も大きくなっている.このことは流動限界 の大きいまさ土は綝返し載荷に対して剛性を保持する能 力が高く,繰返しせん断に対する変形抵抗性が高いことを 示している. そこで, この岡性の低下率を定量的に表現す るため, 粘性土について求めた双曲線関係式で回帰を行っ $た^{9)}$.

$$
\frac{E}{E_{0}}=1-\frac{\Sigma W}{A+B \Sigma W}
$$

ここで, $A, B$ は回帰定数， $\Sigma W$ は累積損失エネルギ一を 示している.

図一12 は双曲線の倸数を求めるための直線近似の結果 である.この図より累積損失エネルギーと $\Sigma W /\left(1-\left(E / E_{0}\right)\right)$ の間には明確な直線関倸が存在することから変形係数の 低下を累積損失エネルギーの双曲線関数で表現すること の妥当性が伺える.この関係式より算出された定数 $1 / A$ は加振初期の変形倸数比の低下率を表しており, 定数 $1 / B$ は最終的な变形係数比の低下率を表している. 液状化過程 
のまさ土の変形挙動を考えるとき, 最終的な変形係数比の 低下率を考えるよりも初期の変形抵抗を表す定数 $1 / A$ を 基淮にした方がよいと考えられる.

そこで,まさ土試料におけるすべての実験結果について 定数 $1 / A$ と流動限界の関係を示したものが図-13 である. 図中の值は間隙比を示している. この図をみると, ほぼ同 じ間隙比の值を等間隙比線として結ぶと定数 $1 / A$ と流動 限界は図中のような曲線関係を持つことになる.

また, 図より流動限界の大きい試料の方が繰返しせん断 初期での変形に対する抵抗性が高く, 変形に対する剛性を より保持しうることがわかる. しかし，流動限界の小さい 試料においては，ある程度まで締固めないと繰返しせん断 初期での変形に対する抵抗力が低く, 規模の小さい地震に おいても変形を起こす可能性があることを示している. し たがって,この関係より,まさ土地船の間隙比と流動限界 から地震動に対する変形抵抗の概略的な判別が可能であ ると考えられる.

\section{6. まとめ}

広範囲の物性值を有するまさ土の液状化特性を表す指 標として流動限界を用いることの妥当性を検討した. そし て液状化過程における損失エネルギーに注目して強度と 変形の立場からまさ土の液状化特性を考察した. その結果, 以下のことが明らかになった。

1）液状化に至るまでの累積損失エネルギ一は，間隙比が 同じであれば綝返し応力振幅比に関わらずほぼ同じ值に なる.このことから従来から用いられている液状化強度曲 線は液状化に至るまでの累積損失エネルギ一の等しい線， すなわち, 等エネルギー線と等価であることがわかった. 2）まさ土の間隙比と流動限界から，液状化に至るまでの 累積損失エネルギーの值を簡便に推定することができる.

3）2）の方法で累積損失エネルギーが推定できると, 図一

13 を用いることで容易に液状化強度曲線を推定すること
ができる. すなわち, 間隙比と流動限界から液状化強度曲 線を直接推定することができることが明らかとなった.

4）流動限界と間隙比を用いることで, 液状化に至るまで の変形抵抗の変化を容易に評価することができる.

最後に本論文を進めるに当たり, 実験に従事して頂いた 元関西大学大学院生 竹田昌史君に感謝する次第である.

\section{参考文献}

1）中山義久, 西田一彦，西形達明，井上啓司：まさ士の物性と 液状化特性，土木学会論文集，№.638/III-49，pp. 207〜215, 1999.

2) Towhata, I. and Ishihara, K. : Shear Work and Pore Water Pressure in Undrained Shear, Soils and Foundations, Vol. 25, No. 3, pp. 73 $\sim 84,1985$.

3）坂井晃, 落合英俊 : せん断仕事に基づく飽和砂地盤の液状化 解析，土木学会論文集，№. 307/III-5，pp. 75 83，1986.

4）片田敏行，阿部幸樹，東山晃 : ひずみエネルギー蓄積効果を 用いた飽和砂の地盤の液状化過程の考察，土木学会論文集， No. 388/III-7, pp. $43 \sim 50,1987$.

5）風間基樹，柳沢栄司，増田昌昭：定ひずみ制御繰返し三軸試 験による液状化強度評価の可能性，土と基礎，第 46 巻, 第 4 号, pp. 21 24, 1998.

6）風間基樹，鈴木崇弘，柳沢栄司：地盤に入力された累積損失 エネルギーの評価法と液状化予測への適用, 土木学会論文集, 第631 号/III-48, pp. 161 177, 1999.

7）運輸省港湾局監修: 港湾の施設の設計上の基淮・同解锐，日 本港湾協会, 上巻, pp. 204 209, 1997.

8) 日本道路協会: 道路橋示方書・同解説，V而震設言十編，pp. 91 $\sim 97,1996$.

9）中山義久, 西田一彦, 西形達明, 井上啓司: 繰返し載荷を受 けた粘性土の変形倸数の低下とその回復, 土木学会論文集, No. 589/III-42, pp. 131〜141, 1998.

(2000.7.3 受付)

\title{
EVALUATION OF LIQUEFACTION OF DECOMPOSED GRANITE SOILS BY MEANS OF FLOW LIMIT AND DISSIPATION ENERGY
}

\author{
Yoshihisa NAKAYAMA, Kazuhiko NISHIDA, Tatsuaki NISHIGATA and Keiji INOUE
}

\begin{abstract}
Deformation characteristics of decomposed granite soils during liquefaction process ware experimentally discussed from results of cyclic tri-axial test. As a result, the accumulated dissipation energy at occurrence of liquefaction depends on the void ratio and flow limit value of the sample of decomposed granite soil, and the approximate liquefaction resistance can be easily estimated from the values of the accumulated dissipation energy. Furthermore, the decrease process of shear modulus during liquefaction is closely related with flow limit value, and has a hyperbolic relation to the accumulated dissipation energy.
\end{abstract}

